RERTATIE MIE MALLED

Campinas-SP, v.39, n.2, pp. 741-767, jul./dez. 2019

\title{
O Hamlet brasileiro de Machado de Assis
}

\section{The Brazilian Hamlet of Machado de Assis}

\author{
Marcelo Diego
}

Resumo: Este ensaio parte de uma provocação em relação à contribuição crítica seminal de Helen Caldwell (com o seu O Otelo brasileiro de Machado de Assis, de 1960), para analisar o diálogo intertextual de Dom Casmurro com o Hamlet de Shakespeare. Para tanto, dá particular atenção à centralidade, no interior do romance e da peça, da figuração do teatro, ou melhor, de processos de encenação; figuração que se dá por meio do desnudamento de uma consciência cênica, de uma forma teatral e de uma visão do mundo como representação. Por fim, sugere que, assim como o resgate da presença de Otelo em Dom Casmurro, então, abriu caminho para que a crítica literária debatesse questões candentes do seu tempo, a recuperação da presença de Hamlet em Dom Casmurro possibilita que a crítica cultural discuta algumas das questões mais prementes dos dias atuais.

Palavras-chave: Machado de Assis; Shakespeare; teatro.

Abstract: This essay starts from a provocation to Helen Caldwell's seminal critical contribution (her The Brazilian Othello of Machado de Assis, from 1960), to discuss Dom Casmurro's intertextual dialogue with Shakespeare's Hamlet. To this end, it pays particular attention to the centrality, in both novel and play, of the figuration of the theater, or rather, of the staging process, which occurs through the stripping of a scenic consciousness, of a theatrical form and of a vision of the world as representation. Finally, it suggests that just as the resurrection of Othello's presence in Dom Casmurro paved the way for literary criticism to debate burning issues of that time, the recovery of Hamlet's presence in Dom Casmurro enables cultural criticism to discuss some of the most pressing issues of the present day.

Keywords: Machado de Assis, Shakespeare, Drama.

1 Professor no Departamento de Ciência da Literatura da Universidade Federal do Rio de Janeiro (UFRJ): <marcelodiego@letras.ufrj.br>. 
A crítica já explorou, com bastante cuidado, a relação entre Dom Casmurro (1900) e Ressurreição (1872), dando a ver como, sob diversos aspectos, o romance de estreia do autor é um balão de ensaio para a sua obra-prima da virada do século. Destaquem-se, entre esses aspectos, o tema do ciúme ${ }^{2}$ e o diálogo intertextual profundo com a dramaturgia shakespeariana. ${ }^{3}$ Ressurreição conta a história de Félix, médico formado que, não obstante, goza uma vida ociosa, graças a uma herança recebida e, aos 36 anos, evita qualquer envolvimento profundo com o outro sexo, dizendo de seus amores que são "todos semestrais; duram mais do que as rosas, duram duas estações. Para o meu coração, um ano é a eternidade”. Para surpresa sua e de todo o seu círculo, acaba cedendo aos encantos da viúva Lívia, irmã de seu amigo Viana; os dois tornam-se noivos, porém Félix é dilacerado por desconfianças em relação à moça (germinadas espontaneamente em sua cabeça ou plantadas pelo malicioso Luís Batista, antigo pretendente de Lívia) e por duas vezes ameaça desmanchar o noivado; na terceira vez, é Lívia quem toma a iniciativa e desfaz o laço que os unia, não podendo mais suportar a ofensa da dúvida de Félix. O comentário final do narrador sobre o protagonista, no capítulo XXIV, retoma em vernáculo os versos da "Advertência":

Dispondo de todos os meios que o podiam fazer venturoso, segundo a sociedade, Félix é essencialmente infeliz. A natureza o pôs nessa classe de homens pusilânimes e visionários, a quem cabe a reflexão do poeta: "perdem o bem pelo receio de o buscar". Não se contentando com a felicidade exterior que o rodeia, quer haver essa outra, das afeições íntimas, duráveis e consoladoras. Não a há de alcançar nunca, porque o seu coração, se ressurgiu por alguns dias,

\footnotetext{
2 "Já foi observado por mais de um crítico - a precedência cabendo a Helen Caldwell, que o afirmou na década de 1960 - que essa matriz romanesca (o amor entre duas pessoas minado pelo ciúme de um homem corroído por dúvidas, fundadas ou não, sobre a fidelidade da mulher), explorada por Machado em Ressurreição, já se esboçava no conto "A mulher de preto', publicado em Contos fluminenses (1870), e atinge a perfeição em Dom Casmurro." (SENNA; DIEGO, 2011, p. 132).

3 A interlocução com o Bardo é estabelecida antes mesmo do início da narrativa, na "Advertência" da primeira edição, quando o escritor reproduz a seguinte passagem de Measure for Measure (SHAKESPEARE, [s.d.3], I, 5): "Our doubts are traitors/ And make us lose the good we oft might win/ By fearing to attempt". A esse respeito, dizem os mesmos autores: "Já então parece o nosso autor preocupado com uma questão que o acompanhará em toda a obra e de que Dom Casmurro será a realização máxima. Note-se que a escolha da passagem revela intimidade com a dramaturgia shakespeariana, uma vez que a opção óbvia seria recorrer a Hamlet, ao famoso solilóquio do terceiro ato: "To be or not to be, that is the question" [Ser ou não ser, eis a questão]; ou mesmo a Otelo, dilacerado pela dúvida que o malévolo Iago lhe planta no coração" (SENNA; DIEGO, 2011, p. 130).
} 
esqueceu na sepultura o sentimento de confiança e a memória das ilusões (ASSIS, 2008b, [s.p.]).

Voltando às insistências de Ressurreição em Dom Casmurro, recebeu pouca atenção - se alguma - o desenvolvimento, na narrativa longa de 1900, de uma metáfora mencionada rapidamente na de 1872: a de que a vida é uma ópera. No capítulo XX, na véspera do casamento de Lívia e Félix, Luís Batista faz uma visita a este; o motivo declarado da visita é pedir ao dono da casa, como favor, que lhe ceda certa gravura representando o rei Davi à espreita de Betsabé durante o banho, ${ }^{4}$ a fim de oferecê-la a uma amante, que se havia enamorado pelo quadro, ao admirá-lo em uma loja, antes de ele ser adquirido por Félix. Contudo, o motivo real da presença de Luís Batista na casa de seu rival é ser testemunha da reação do anfitrião ao receber um bilhete anônimo (enviado, é claro, por ele mesmo, Luís Batista), que lhe é entregue naquele momento, contendo uma denúncia contra Lívia. Ao descrever as circunstâncias que o levavam a pedir a gravura a Félix, o inoportuno convidado é "acintosamente leviano", valendo-se de um estilo "galhofeiro e sensual" (ASSIS, 2008b, [s.p.]), razão pela qual ele mesmo observa:

- Não desconheço - disse Luís Batista quando concluiu a sua expansão amorosa -, não desconheço que uma aventura destas, em véspera de noivado, produz igual efeito ao de uma ária de Offenbach no meio de uma melodia de Weber. Mas, meu caro amigo, é lei da natureza humana que cada um trate do que lhe dá mais gosto. A vida é uma ópera bufa com intervalos de música séria. O senhor está num intervalo; delicie-se com o seu Weber até que se levante o pano para recomeçar o seu Offenbach. Estou certo de que virá cancanear comigo, e afirmo-lhe que achará bom parceiro (ASSIS, 20o8b, [s.p.]).

Note-se que a metáfora que ganha forma na fala de Luís Batista é composta por duas imagens, independentes, porém complementares. A primeira é a de "uma ária de Offenbach no meio de uma melodia de Weber" (em que se pode ouvir um eco do "tiro de pistola no meio de um concerto", de A cartuxa de Parma - atente-se ao rebaixamento efetuado pela alusão, uma vez que, no romance de Stendhal, a imagem serve para descrever a intromissão da política na literatura, assunto muito mais elevado do que casos de namoro às vésperas de casamento). Se, para compreender a referência, o leitor de 1872 deveria estar familiarizado com as obras dos dois compositores (o sisudo Weber e o ligeiro Offenbach),

4 Sobre o episódio bíblico e sua função na trama do romance, ver: Senna (2008, p. 28).

Remate de Males, Campinas-SP, v.39, n.2, pp. 741-767, jul./dez. 2019 - 743 
ele perceberia um anacronismo na narrativa: a "Advertência" do romance é datada de 1872 , e o primeiro capítulo começa por dizer que "já lá vão dez anos!", o que remeteria a ação para 1862; no entanto, os dois grandes sucessos de Offenbach junto ao público fluminense (o Orphée aux enfers, de 1858, e La Belle Hélène, de 1864) estrearam no Rio de Janeiro apenas em 3 de fevereiro de 1865 e em 26 de junho de 1866, respectivamente, ambos no Alcazar Lyrique de M. Arnaud (MAGALDI, 2004, p. 97). A referência, portanto, estava disponível para o narrador da história, em 1872, mas não para suas personagens, em 1862.

A segunda imagem é a de que "a vida é uma ópera”, atualização do antigo tópos literário do theatrum mundi, o "teatro do mundo", de que Machado de Assis já se apropriara e ainda se apropriaria algumas vezes. Justapostas as duas imagens, chega-se à metáfora final, tão cara ao autor quanto à sua personagem: não apenas a vida é uma encenação, como é a encenação de um espetáculo essencialmente contraditório, marcado por uma espécie de trauma disjuntivo, responsável pela sua complexidade e beleza.

Sob novas vestes, a metáfora ressurge em Dom Casmurro. O narrador-personagem diz tê-la ouvido de Marcolini, "um velho tenor italiano que aqui [no Rio de Janeiro] viveu e morreu”, pintado como um histriônico, que "Quando andava, apesar de velho, parecia cortejar uma princesa da Babilônia” (ASSIS, 2010, [s.p.]) - reminiscência, quem sabe, de uma atuação no Nabucco de Verdi, que integrava o repertório lírico fluminense desde $1848 . .^{5}$ A passagem, retirada do capítulo IX, embora longa, vale a pena ser reproduzida:

\footnotetext{
5 Ao que tudo indica, a principal fonte de inspiração para a composição da personagem Marcolini - de onde vieram a sua passionalidade, o seu quê de decadente e a sua constante sensação de falta de reconhecimento - foi o maestro Marino Mancinelli, que desembarcou na já então capital federal em julho de 1891, junto com a Companhia Italiana que vinha instalar-se no Teatro Lírico da rua da Guarda Velha (DIÁRIO DE NOTÍCIAS, 16.05.1891, p. 1). Mancinelli rapidamente conquistou a admiração e o carinho do público fluminense, tendo sido o responsável pela estreia do Falstaff (de cujo personagem-título também há traços em Marcolini), de Verdi, às margens da Guanabara, em 1893 (o6.05.1893, p. 1). Todavia, era despreparado para os negócios e assumiu dívidas as quais não tinha condições de honrar; envergonhado diante de seus credores, suicidou-se com um único tiro no crânio, em seu escritório no Teatro, na manhã de 3 de setembro de 1894 (GAZETA DE NOTÍCIAS, Rio de Janeiro, 04.09.1894, p. 1). Já o nome "Marcolini” foi pego de empréstimo à célebre contralto Marietta Marcolini (Florença, 1780-1855), para quem Rossini criou, entre outras, a Isabella de L'Italiana in Algeri (CALDWELL, 1960, p. 57).
} 
- A vida é uma ópera e uma grande ópera. O tenor e o barítono lutam pelo soprano, em presença do baixo e dos comprimários, quando não são o soprano e o contralto que lutam pelo tenor, em presença do mesmo baixo e dos mesmos comprimários. Há coros numerosos, muitos bailados, e a orquestração é excelente...

- Mas, meu caro Marcolini...

- Quê...?

E, depois de beber um gole de licor, pousou o cálix, e expôs-me a história da criação, com palavras que vou resumir.

Deus é o poeta. A música é de Satanás, jovem maestro de muito futuro, que aprendeu no conservatório do céu. Rival de Miguel, Rafael e Gabriel, não tolerava a precedência que eles tinham na distribuição dos prêmios. Pode ser também que a música em demasia doce e mística daqueles outros condiscípulos fosse aborrecível ao seu gênio essencialmente trágico. Tramou uma rebelião que foi descoberta a tempo, e ele, expulso do conservatório. Tudo se teria passado sem mais nada, se Deus não houvesse escrito um libreto de ópera, do qual abrira mão, por entender que tal gênero de recreio era impróprio da sua eternidade. Satanás levou o manuscrito consigo para o inferno. Com o fim de mostrar que valia mais que os outros - e acaso para reconciliar-se com o céu -, compôs a partitura, e logo que a acabou foi levá-la ao Padre Eterno.

- Senhor, não desaprendi as lições recebidas - disse-lhe. Aqui tendes a partitura, escutai-a, emendai-a, fazei-a executar, e se a achardes digna das alturas, admiti-me com ela a vossos pés...

- Não - retorquiu o Senhor -, não quero ouvir nada.

- Mas, Senhor...

- Nada! Nada!

Satanás suplicou ainda, sem melhor fortuna, até que Deus, cansado e cheio de misericórdia, consentiu em que a ópera fosse executada, mas fora do céu. Criou um teatro especial, este planeta, e inventou uma companhia inteira, com todas as partes, primárias e comprimárias, coros e bailarinos.

- Ouvi agora alguns ensaios!

- Não, não quero saber de ensaios. Basta-me haver composto o libreto; estou pronto a dividir contigo os direitos de autor.

Foi talvez um mal esta recusa; dela resultaram alguns desconcertos que a audiência prévia e a colaboração amiga teriam evitado. Com efeito, há lugares em que o verso vai para a direita e a música, para a esquerda. Não falta quem diga que nisso mesmo está a beleza da composição, fugindo à monotonia, e assim explicam o terceto do Éden, a ária de Abel, os coros da guilhotina e da escravidão. Não é raro que os mesmos lances se reproduzam, sem razão suficiente. Certos motivos cansam à força de repetição. Também há obscuridades; o maestro abusa das massas corais, encobrindo muita vez o sentido por um modo confuso. As partes orquestrais são aliás tratadas com grande perícia. Tal é a opinião dos imparciais.

Os amigos do maestro querem que dificilmente se possa achar obra tão bem acabada. Um ou outro admite certas rudezas e tais ou quais lacunas, mas com o andar da ópera é provável que estas sejam preenchidas ou explicadas, e aquelas desapareçam inteiramente, não se negando o maestro a emendar a obra onde achar que não responde de todo ao pensamento sublime do poeta. Já não dizem o mesmo os amigos deste. Juram que o libreto foi sacrificado, que a partitura corrompeu o sentido da letra, e, posto seja bonita em alguns lugares, 
e trabalhada com arte em outros, é absolutamente diversa e até contrária ao drama. O grotesco, por exemplo, não está no texto do poeta; é uma excrescência para imitar as Mulheres patuscas de Windsor. Este ponto é contestado pelos satanistas com alguma aparência de razão. Dizem eles que, ao tempo em que o jovem Satanás compôs a grande ópera, nem essa farsa nem Shakespeare eram nascidos. Chegam a afirmar que o poeta inglês não teve outro gênio senão transcrever a letra da ópera, com tal arte e fidelidade, que parece ele próprio o autor da composição; mas, evidentemente, é um plagiário.

- Esta peça - concluiu o velho tenor - durará enquanto durar o teatro, não se podendo calcular em que tempo será ele demolido por utilidade astronômica. O êxito é crescente. Poeta e músico recebem pontualmente os seus direitos autorais, que não são os mesmos, porque a regra da divisão é aquilo da Escritura: "Muitos são os chamados, poucos, os escolhidos". Deus recebe em ouro, Satanás, em papel.

- Tem graça...

- Graça? - bradou ele com fúria; mas aquietou-se logo, e replicou -: Caro Santiago, eu não tenho graça, eu tenho horror à graça. Isto que digo é a verdade pura e última. Um dia, quando todos os livros forem queimados por inúteis, há de haver alguém, pode ser que tenor, e talvez italiano, que ensine esta verdade aos homens. Tudo é música, meu amigo. No princípio era o dó, e o dó fez-se ré, etc. Este cálix (e enchia-o novamente), este cálix é um breve estribilho. Não se ouve? Também não se ouve o pau nem a pedra, mas tudo cabe na mesma ópera... (ASSIS, 2010, [s.p.]).

Para Marcolini, como para Luís Batista, “a vida éuma ópera”. A razãodas eventuais desarmonias do espetáculo, para o coadjuvante de Ressurreição, reside no fato de a vida ser "uma ópera bufa com intervalos de música séria”, enquanto para o comprimário de Dom Casmurro deve- se às divergências entre o libreto (de Deus) e a música (de Satanás). Uma por meio de alusão ao repertório lírico e outra por meio de evocação da tradição cristã, ambas as personagens identificam um tipo de dissonância - o choque entre sério e bufo, entre Deus e Satanás -, que faz com que, na "grande ópera" da vida, por vezes "o verso [vá] para a direita e a música, para a esquerda”. A diferença fundamental entre os discursos de Luís Batista e Marcolini é que o do primeiro contém uma metáfora, enquanto o do segundo expõe uma teoria. Para o rival de Félix, a frase "a vida é uma ópera” é simplesmente uma comparação sem conjunção, e não uma concepção da realidade; ele poderia igualmente dizer que "a vida é como uma ópera”. Já para o velho tenor, "a vida é uma ópera" "é a verdade pura e última”, lição heterodoxa do texto do Gênesis, que ele professa fervorosamente. Além disso, ao passo em que na metáfora de Luís Batista o trauma disjuntivo, ou pecado original, encontra-se, basicamente, no plano do conteúdo - a oposição entre ópera séria e cômica -, na teoria de Marcolini, ele pertence ao plano da forma, ou melhor, da linguagem - a dissociação entre libreto e partitura, no drama 
lírico. Entre a metáfora da vida como ópera de Ressurreição e a teoria da vida como ópera de Dom Casmurro estão três décadas de amadurecimento de Machado de Assis como escritor e como diletante. Cumpre examinar alguns pontos desse percurso.

O capítulo IX, "A ópera”, destaca-se de Dom Casmurro como uma digressão, nada acrescentando à progressão do enredo. Sua função é suplementar, colaborando tanto com a caracterização de personagem (revela um Bento escarninho e mesquinho, que ridiculariza Marcolini e se vale do credo do tenor da maneira mais utilitária possível), quanto com o estabelecimento da moldura metanarrativa do romance, conforme se verá. Quer pelo seu caráter digressivo, quer pelo seu conteúdo cosmogônico, lembra o capítulo VII das Memórias póstumas de Brás Cubas, "O delírio" (em um quiasmo que enlaçasse os dois romances e os dois capítulos, o capítulo "A ópera" bem poderia ser descrito como um delírio do narrador-personagem de Dom Casmurro, assim como "O delírio" poderia ser descrito como uma ópera bufa concebida pelo narrador-personagem de Memórias póstumas de Brás Cubas). Considerado no interior da prosa de ficção machadiana como um todo, o capítulo "A ópera” guarda semelhanças com duas famílias de contos.

A primeira é a dos contos filosóficos - de larga tradição na literatura, como provam os contes philosophiques franceses, de que Machado era leitor contumaz -, em que a trama se dispõe, claramente, de modo a lançar os termos de uma perquirição filosófica. À guisa de exemplo, pense-se em “O espelho" (Gazeta de Notícias, 1882, e Papéis avulsos) (ASSIS, 2012, [s.p.]), cujo subtítulo já esclarece tratar-se de um "esboço de uma nova teoria da alma humana”. Integra essa família, igualmente, uma variedade de contos pseudofilosóficos (porque os problemas que armam não são de natureza propriamente filosófica, e sim moral ou psicológica, sob a perspectiva do senso comum) ou metafilosóficos (porque têm como ponto focal o questionamento ou desconstrução de outras correntes filosóficas). Produzidos a partir do fim da década de 1870, compõem parte expressiva das coletâneas Papéis avulsos (1882), Histórias sem data (1884) e Várias histórias (1896).

Ocupam lugar privilegiado, entre os contos filosóficos machadianos, as sátiras religiosas, narrativas em que o escritor se apropria de elementos das Sagradas Escrituras - de episódios, de personagens, até mesmo do estilo - e os relê em chave própria. Os casos mais notáveis desse tipo de narrativa são "Na arca" (O Cruzeiro, 1878, e Papéis avulsos), "A igreja 
do diabo" (Gazeta de Notícias, 1883, e Histórias sem data), "Adão e Eva” (Gazeta de Notícias, 1885, e Várias histórias) e "Entre santos" (Gazeta de Notícias, 1886, e Várias histórias). ${ }^{6}$ E, pela emenda que realiza no Livro do Gênesis, "A ópera” compõe com essa galeria.

O caráter alegórico e o elemento fantástico que caracterizam essas narrativas também estão presentes na crônica machadiana. Uma das "Histórias de quinze dias", de 1876, guarda não poucas afinidades com o capítulo "A ópera", de Dom Casmurro, situando-se a meio caminho entre a metáfora de Luís Batista e a teoria de Marcolini (a crônica, tal como praticada por Machado, como zona de deslizamento da não ficção para a ficção e vice-versa, constitui lugar privilegiado para esse tipo de operação):7

Conheço um homem que anda meio desconfiado de que não há guerra da Sérvia nem império turco; consequentemente, que não há sultões caídos, nem suicidados. Mas que são as notícias com que os paquetes vêm perturbar nossas digestões? Diz ele que é uma ópera de Wagner e que os jornais desta corte traduzem mal as notícias que acham nos estrangeiros. A ópera, segundo este meu amigo, intitula-se "Os três sultões ou O sonho do grão-vizir", música de Wagner e libreto de Gortchakoff. Tem numerosos quadros. A introdução no estilo herzegoviano é um primor, conquanto fosse ouvida sem grande atenção por parte do público. A atenção começou quando rompeu o dueto entre Milano e Abdul-Aziz, e depois o coro do softas, que derrocam Abdul... $\mathrm{O}$ mais sabemos todos. A este meu amigo, replico eu dizendo que a coisa não é ópera, mas guerra; sendo prova disso o telegrama há dias publicado, que trouxe a notícia de achar-se em começo de paz. Respondeu-me que é ilusão minha. "Há decerto um coro" que entra cantando: Pace, pace, mas é um coro. Que queres tu? Antigamente as óperas eram música, hoje são isso e muita coisa mais. Vê os Huguenotes, com a descarga de tiros no fim. Pois é a mesma coisa a nova composição de Wagner. Há tiros, batalhões, mulheres estripadas, crianças partidas ao meio, aldeias reduzidas a cinzas, mas é tudo ópera (ILUSTRAÇÃO BRASILEIRA, 01.10.1876, p. 1).

A segunda família de contos com a qual "A teoria" guarda parentesco é a dos contos musicais. Chama atenção que Machado de Assis, escritor, tenha privilegiado sistematicamente, em seus contos, a figuração de músicos, em vez da de escritores, pintores, escultores etc. (o mesmo não se verifica, evidentemente, no campo do romance, uma vez que Memórias póstumas de Brás Cubas, Dom Casmurro e Memorial de Aires são, antes de tudo, encenações de processos escriturais). Sua investigação sobre o ato criativo, sobre a inspiração e a transpiração do artista, é feita, no terreno

6 Para uma leitura circunstanciada da utilização de recursos satíricos, em especial do pastiche, no conto machadiano, ver: Diego (2008).

7 A esse respeito, ver: Granja (2018).

Remate de Males, Campinas-SP, v.39, n.2, pp. 741-767, jul./dez. 2019 - 748 
da narrativa curta, por meio da música, em contos como "O machete" (Jornal das Famílias, 1878), "Cantiga de esponsais" (A estação, 1883, e Histórias sem data), “Trio em lá menor" (Gazeta de Notícias, 1886, e Várias histórias) e "Um homem célebre" (Gazeta de Notícia, 1888, e Várias histórias). ${ }^{8}$ Aliás, notas do primeiro título da lista, "O machete", ecoam no capítulo CXXVII de Dom Casmurro, “O barbeiro”: em ambos está presente a ideia (que, no conto, de fato se realiza, enquanto no romance fica apenas sugerida) do músico tão embevecido com a própria arte, que é incapaz de impedir que a mulher lhe escape por entre os dedos.

Alembrança do episódio do barbeiro faz parte dos esforços deliberados do narrador para, com o auxílio de alusões e comparações, convencer o leitor da traição de Capitu: ${ }^{9}$ também ela teria sido namorada sob as suas barbas, enquanto ele, qual pobre artista, cumpria, sem olhos nem ouvidos para nada, o seu papel na ópera da vida. Note-se que o episódio surge a uma altura do romance em que não apenas o tópos do theatrum mundi, de maneira geral, fora pisado e repisado, em capítulos como "A ópera" (IX), "Uma reforma dramática” (LXXII) e “O contrarregra” (LXXIII), mas também o narrador-personagem já reclamara para si o estatuto de artista: "Cantei um duo terníssimo, depois um trio, depois um quatuor..." (ASSIS, 2010, [s.p.]). Contudo, o comentário final do narrador - ou do autor, que faz as vezes do inconsciente do narrador, inserindo lapsos no seu discurso - sobre a anedota do barbeiro carrega consigo uma ambiguidade: "Supõe agora que este [o transeunte], em vez de ir-se embora, como eu fui, ficava à porta a ouvi-lo e a enamorar-lhe a mulher; então é que ele, todo arco, todo rabeca, tocaria desesperadamente. Divina arte!". A reação do artista ("todo arco, todo rabeca, tocaria desesperadamente") dever-se-ia ao fato de o transeunte ficar "à porta a ouvi-lo", ou de "enamorar-lhe a mulher"? A segunda possibilidade saca o barbeiro (e o Bento Santiago que, narrando sua história, busca uma chancela para a mesma) do lugar da vítima,

8 Tendo como ponto de partida este último, o ensaio "Machado maxixe", de José Miguel Wisnik, continua sendo a leitura mais completa sobre a música (e os músicos) na obra de Machado de Assis. Cf. Wisnik (2003).

9 Para tanto, a estrutura memorialística do romance é fundamental, uma vez que o narrador Casmurro se posiciona em um momento posterior àquele em que situa a personagem Bento. Nas palavras de Juracy Assmann Saraiva (1993, p. 105), "O domínio do universo diegético e a referencialidade temporal permitem a Dom Casmurro reinterpretar os episódios do relato; salientar os procedimentos das demais personagens que condizem com os objetivos dele; antecipar fatos que, em relação à história, ainda devem ocorrer; e, sobretudo, selecionar acontecimentos cuja evolução registra a metamorfose de Bento Santiago em Dom Casmurro". 
convertendo o marido em parte integrante e interessada de qualquer aventura extraconjugal da mulher. ${ }^{10}$

Cabe lembrar que a expansão horizontal e vertical da música na ficção machadiana corresponde à progressão da educação musical do autor educação dependente de fatores externos, mais lenta e errática do que a literária. Ainda nos anos 186o, fez-se amigo de Artur Napoleão, antigo menino prodígio, pianista de carreira e editor musical. Àquela época, Machado começou a frequentar os saraus musicais e literários organizados por Napoleão, em sua residência à rua da Quitanda, de que também tomavam parte o pianista Schramm, o violinista Moniz Barreto e o flautista Reichert (SAYERS, 1968, pp. 778-779). Quando tanto Machado quanto Napoleão se casaram, suas mulheres fizeram-se amigas; e a convivência dos casais tornou-se ainda mais próxima a partir do momento em que Napoleão e a mulher mudaram-se para Laranjeiras, ao pé de Machado e Carolina, que viviam no Cosme Velho. Frequentavam os mesmos círculos que o escritor, a esse tempo, e eram seus interlocutores a propósito de assuntos musicais, os maestros Alberto Nepomuceno, Francisco Braga e Leopoldo Miguez. Se a cultura musical de Machado, no início dos anos 1870, era a mesma de qualquer homem minimamente cultivado do seu tempo, no início dos anos 188 o ela já era a de um entusiasta, dotado de sensibilidade para a arte e de uma escuta educada. Quando o exclusivo Club Beethoven foi fundado, em 1882 (MAGALDI, 2004, p. 75), o autor de Memórias póstumas de Brás Cubas somou-se às suas frentes, como associado e membro da diretoria.

Além disso, o repertório lírico do autor de Ressurreição e das personagens de Dom Casmurro, em 1872, era significativamente menor do que o do narrador de Dom Casmurro, em 1900. Este, durante a maior parte do romance, é pródigo e exato com datas; deixa de sê-lo apenas após a morte de Escobar, quando começa a levantar suspeitas sobre a suposta traição de Capitu com seu "amigo e comborço". Nesse sentido, é interessante observar como, ao instalar-se a dúvida, qual "ideia fixa”, na cabeça de Bentinho, a sua noção de tempo torna-se inteiramente subjetiva, perdendo a conexão com o mundo objetivo. Antes disso, contudo, a cronologia é precisa:

\footnotetext{
10 O romance que precedeu o Dom Casmurro, Quincas Borba, tematiza de forma explícita esse tipo de trama erótica: nele, Cristiano Palha insta sua mulher, Sofia, a não desencorajar o interesse que Rubião nutre por ela. O motivo principal é financeiro (Palha e Sofia devem dinheiro a Rubião), porém há também boa medida de comprazimento, por parte do marido, em ver a mulher cobiçada por outro. Para uma leitura do Dom Casmurro nessa linha, ver: Diego (2017).
}

Remate de Males, Campinas-SP, v.39, n.2, pp. 741-767, jul./dez. 2019 - 750 
a cena da denúncia, no capítulo III, ocorre em 1857, tendo Bentinho 15 anos, o que faz seu nascimento remontar a 1842; dos 15 aos 17 (1857-1859), frequenta o seminário; dos 18 aos 22 (1860-1864), o curso de Direito; aos 23 (1865), casa-se; aos 29 (1871), perde o melhor amigo; e aos 30 (1872), começa a vislumbrar traços de Escobar em Ezequiel. A partir daí, as datas, como a percepção do personagem-narrador, perdem a nitidez; porém, a sua obsessão progride rapidamente, de modo que é lícito supor que ao redor de 1875 Capitu já residisse na Suíça." Teria Bentinho, então, 33 anos; e, por ocasião da publicação de suas memórias, 58 .

Quando, no capítulo C, “Tu serás feliz, Bentinho”, com a carta de bacharel na mão e às portas do Céu - do tão aguardado casamento com Capitu -, o filho de D. Glória ouve "uma fada invisível”, que lhe diz "em voz igualmente macia e cálida: 'Tu serás feliz, Bentinho; tu vais ser feliz”, o narrador sugere ser essa fada "prima das feiticeiras da Escócia”, que haviam vaticinado ao então general do rei Duncan: "Tu serás rei, Macbeth!" (ASSIS, 2010, [s.p.]). É provável que um e outro, narrador e personagem, conhecessem o texto da tragédia de Shakespeare (1606), porém é igualmente provável que tenha colaborado para que a cena das Bruxas ficasse gravada na mente de ambos (aliás, a mesma) o acompanhamento musical e o aparato cênico da ópera Macbeth (1852), de Verdi, cuja estreia na Corte marcara a inauguração, em 1852, do Teatro Provisório - a três quadras da rua de Matacavalos, diga-se de passagem. Do mesmo modo, quando o tenor Marcolini, ao expor sua teoria (capítulo IX, "A ópera” ASSIS, 2010, [s.p.]), diz que "O grotesco, por exemplo, não está no texto do poeta; é uma excrescência para imitar as Mulheres Patuscas de Windsor", é bastante possível que sua intimidade com o enredo dessa obra venha não do texto shakespeariano (1602), e sim do Falstaff verdiano, que estreou no Rio de Janeiro em julho de 1893, menos de seis meses depois de sua prima assoluta em Milão, em fevereiro desse ano. ${ }^{12}$

Caso mais complicado é o das referências a Otelo, que aparecem nos capítulos LXII, "Uma ponta de Iago"; LXXII, "Uma reforma dramática”; CXXXV, "Otelo"; e CXXXVI, “A xícara de café”. A convocação insistente da

11 Baseada na evolução das descrições de Ezequiel (nas marcas do seu crescimento), Vasconcelos (2009) estima que o processo obsessivo de Bentinho tenha durado entre um e dois anos, contados a partir de 1872 .

12 Corrobora com essa suposição o fato, já mencionado, de ter sido o maestro suicidário Marino Mancinelli a principal fonte de inspiração para a personagem de Marcolini, o regente do Falstaff, na temporada de estreia da ópera no Teatro Lírico, antigo Teatro de D. Pedro II (e, antes disso, Circo Olímpico), no Rio de Janeiro. 
tragédia do mouro de Veneza revela a intimidade do narrador-personagem com ela, o que não causa espanto, uma vez que ele pode ter tido contato com a peça de quatro formas distintas. A primeira é por meio do próprio texto shakespeariano (1603), disponível no original e em traduções, nas melhores livrarias, bibliotecas e gabinetes de leitura. $\mathrm{O}$ autor por trás do narrador casmurro, por exemplo, tinha em sua biblioteca mais de uma edição do Bardo: os treze volumes da coleção Shakespeare, the Hand Volume, de 1868; a antologia The beauties of Shakespeare, de 1839; e os dez volumes da obra completa, vertida para o francês, editada entre $1867 \mathrm{e}$ $1872 .{ }^{13}$ A segunda forma é através de encenações da peça: João Caetano foi o responsável pela introdução do drama nos palcos brasileiros, em 1837, ${ }^{14}$ e Ernesto Rossi e Tommaso Salvini, pelo seu reavivamento, em 1871. A terceira forma teria sido via a ópera de Rossini (1816), que estreara na Corte em 6 de agosto de 1855, com a célebre Lagrua no papel de Desdêmona (SILVA, 1938, p. 448). Por fim, a quarta forma seria a ópera de Verdi (1887), que estreou no Teatro D. Pedro II em 24 de agosto de 1889 (JORNAL DO COMMERCIO, 24.08.1889, p. 6).

Claro está que a ópera de Verdi esteve acessível ao narrador, porém não à personagem, no tempo da narrativa; e que, portanto, quando Bento Santiago assiste a Otelo, no capítulo CXXXV - situado, conforme discutido, entre os anos de 1872 e 1875 -, pode se tratar apenas da peça, na interpretação de Rossi ou Salvini, ou da ópera de Rossini. Sem embargo, quem se recorda de ter assistido a esse Otelo e insere essa recordação em um ponto fulcral das suas memórias é o narrador - este sim, para quem a tragédia de Otelo conta com uma incontornável camada expressiva dada por Verdi. A insistência nesse ponto nãoé gratuita: ela quer chamaratenção para a importância da mediação verdiana da recepção de Shakespeare pelo narrador. Esse narrador - para quem a vida é uma ópera, para quem o destino é um dramaturgo e contrarregra, e que já cantou o seu duo,

13 Cf. Jobim (2001). Sílvia Azevedo (2008, p. 33) pondera que "Por volta de 1870, Machado de Assis já estaria lendo Shakespeare, muito provavelmente no original, a tomar como indício o poema 'A morte de Ofélia', 'paráfrase em verso' do episódio no Hamlet, de Shakespeare, que, vindo a integrar o livro Falenas, não foi aproveitada pelo autor na sua edição das Poesias completas (1901)".

14 “Trata-se, na verdade, de um Otelo que resultou de 'tripla pulverização', nas palavras de Joaquim Nabuco: em primeiro lugar, a adaptação da peça shakesperiana por Jean-François Ducis ao gosto da tragédia francesa do século XVIII; em seguida, a tradução em verso para o português por Domingos José Gonçalves de Magalhães; por fim, a interpretação de João Caetano do Otelo, marcada, no relato de Joaquim Manuel de Macedo, 'pela exageração dos impulsos apaixonados, pelos gritos selvagens e desentoados”' (AZEVEDO, 2008, p. 27).

Remate de Males, Campinas-SP, v.39, n.2, pp. 741-767, jul./dez. 2019 - 752 
o seu trio e o seu quatuor - certamente teria uma leitura das Mulheres patuscas de Windsor, do Macbeth e do Otelo de Shakespeare - únicas peças do autor mencionadas -, matizada pelo Falstaff, o Macbeth e o Otelo de Verdi. As consequências dessa mediação são duas: a apropriação das peças pelo prisma do melodrama (somente a sua trama mais aparente, os seus sentimentos mais apaixonados, as suas ações mais contundentes); e a omissão, oportuna e cômoda, da peça de Shakespeare com a qual a sua história guarda maior identidade - Hamlet.

Muito já se falou a respeito do caráter não confiável do narrador de Dom Casmurro, de como ele mesmo confessa a sua má memória, as suas imprecisões, a sua tendência à digressão. Do mesmo modo, muita tinta já foi gasta para descrever a feição de peça de acusação que ele dá à narrativa, os mecanismos por meio dos quais tenta condicionar, a seu favor, a recepção do leitor. Sem embargo, uma das riquezas do texto de Machado de Assis é que ele dá voz não apenas ao que o narrador quis dizer, mas também ao que ele não soube calar. Assim, habitam o discurso do Dom Casmurro uma corrente e uma contracorrente: a sua narração quer demonstrar a culpa de Capitu; contudo, certas insistências e certos lapsos do narrador parecem querer revelar culpas do próprio Bento Santiago. As alusões literárias, ao fazerem pousar uma segunda mão sobre a mão que segura a pena - ao introduzirem uma segunda voz no discurso e, assim, desestabilizá-lo -, são particularmente propícias para que ocorram atos-falhos, para que o inconsciente do narrador aflore em seu discurso.

No capítulo C - “Tu serás feliz, Bentinho" -, por exemplo, o narrador vale-se da referência à cena das bruxas, de Macbeth, como uma espécie de pátina, um verniz de grandiosidade e transcendência com o qual doura o seu sentimento de expectativa, de confiança no próprio futuro, que haveria de ser promissor, como lhe garantia, afinal, o seu estatuto de cor e classe. Absorto no gozo de seus privilégios, o narrador-personagem compara-se a Macbeth, tendo em vista apenas a face heroica deste; no entanto, a tomar a risca e a sério as suas palavras, a comparação teria de se estender, igualmente, à face anti-heroica da personagem shakespeariana, ao Macbeth traidor, assassino do soberano a quem devia lealdade e de duas crianças indefesas, e cuja ambição desenfreada faz com que a mulher se suicide e ele mesmo seja morto. Os traços do protagonista da scottish play que o narrador-personagem de Dom Casmurro se esquece de mencionar são iguais aos seus próprios traços dos quais quer se esquecer: também ele traiu, com sua desconfiança, aqueles a quem 
devia lealdade; também ele assassinou, simbolicamente, uma criança indefesa; e também ele foi o responsável pela morte em vida de sua mulher e de si próprio.

No que diz respeito à relação entre Dom Casmurro e Otelo, o memorialista do Engenho Novo vincula a sua história à do mouro de Veneza, em primeiro lugar, por meio da insistência: conforme mencionado anteriormente, há referências a ela em quatro passagens da narrativa; e, em segundo, pela identificação do seu turbilhão emocional com o do general do exército veneziano (no capítulo CXXXV, “Otelo"). Nesse mesmo capítulo, comenta consigo: “- E era inocente - vinha eu dizendo rua abaixo -; que faria o público, se ela deveras fosse culpada, tão culpada como Capitu?". Bento Santiago, portanto, apega-se ao Otelo não porque a peça (ou a ópera - neste caso, a de Rossini) espelhe um fato - a culpa de Capitu -, mas porque ela reflete um estado de espírito - o seu ciúme. Em outras palavras, ele se vale do Otelo não para confirmar a traição da mulher (o que não faria sentido, uma vez que ele a compara a Desdêmona, que é sabidamente inocente), e sim para legitimar a autoridade do seu mundo interno sobre o mundo externo, baseando-se, para tanto, na ideia de que a "verossimilhança [...] é muita vez toda a verdade" (ASSIS, 2010, [s.p.]), plantada já no capítulo X, "Aceito a teoria”, espécie de coda ao capítulo IX, "A ópera”. O narrador de Dom Casmurro recorre à comparação com o Otelo como meio de justificar o seu arbítrio diante da suspeita; no entanto, a comparação é incompleta, parcial; e, naquilo que ele não fala sobre a obra literária a que alude, fala o seu sintoma: na tragédia que tem lugar na ilha de Chipre, há um terceiro que produz evidências materiais contra Desdêmona - Iago -, enquanto na tragédia que tem lugar no bairro da Glória, é o próprio Bento quem fabrica, a partir de suas fantasias, as provas com que condena Capitu.

Durante os sessenta anos que se seguiram à publicação de Dom Casmurro, a crítica, de modo geral, deixou-se convencer pela retórica do narrador do romance. Apenas a partir de 1960, leituras orientadas pela crítica feminista, pela sociologia da literatura e pela teoria da desconstrução $0^{15}$ permitiram que se enxergassem os embustes perpetrados

15 A referência é a Helen Caldwell, Roberto Schwarz e Silviano Santiago, respectivamente. Caldwell, com a publicação de The Brazilian Othello of Machado de Assis, em 1960, promoveu uma reviravolta nos estudos machadianos, lançando luzes, pela primeira vez, 
por esse ardiloso narrador machadiano, bem como as agendas implícitas do seu discurso. Em um momento como no outro, a identificação com o Otelo, sugerida pelo narrador, foi considerada elemento estruturante do romance: primeiro, na esteira da argumentação de Bento Santiago, por legitimar o seu ciúme e, portanto, a sua condenação de Capitu; depois, a contrapelo da retórica do narrador-personagem e observando as semelhanças entre a narrativa e o drama como um todo, por depor em favor da inocência de Capitu. Seriam necessárias mais algumas décadas de investimento crítico sobre a obra de Machado de Assis, para que fosse posto em xeque o diálogo entre Dom Casmurro e Otelo: pelos motivos expressos pelo narrador ou pelos motivos omitidos por ele (e resgatados pela crítica), seria Dom Casmurro, de fato, o Otelo brasileiro de Machado de Assis? O caso contra a associação do drama da praia da Glória com a tragédia do mouro de Veneza foi defendido pela primeira vez, de maneira explícita, por Helder Macedo (1991, pp. 17-18), na década de 1990:

\begin{abstract}
Porque substituir o principal pelo acessório é, ${ }^{16}$ efetivamente, o que o narrador deseja que seja feito, para preservar o seu "hábito externo". Fá-lo de diversos modos através do livro, e com particular empenho na pista falsa que é a associação do seu problema pessoal com a tragédia de Otelo - e não há nada mais acessório do que um lenço -, e como o leitor faria se discutisse com ele se a sua Desdêmona é ou não culpada. [...] É também desse modo que Bento Santiago deseja que sua tragédia seja entendida, do fim para o princípio, da conclusão para a premissa, de Dom Casmurro para Bentinho, numa retrospecção disfarçada de prospecção que torne verosímil o adultério da sua Desdêmona culpada, Capitu, com o seu melhor amigo e colega de seminário, Escobar. Só
\end{abstract}

sobre as especificidades do lugar de fala do narrador machadiano. Nele, a professora de Estudos Clássicos da University of California, Los Angeles, denunciava o monopólio do discurso por parte da personagem masculina e propunha a releitura da intertextualidade com o Otelo de Shakespeare como meio de dar voz e visibilidade à personagem feminina. Schwarz, em Ao vencedor as batatas, de 1977, foi o primeiro a descrever de maneira consistente a figuração do processo social na ficção de Machado de Assis; Um mestre na periferia do capitalismo viria em 1990, e "A poesia envenenada de Dom Casmurro", centrada especificamente nesse romance, em 1997, no livro Duas meninas. Santiago, no ensaio "Retórica da verossimilhança", que integra Uma literatura nos trópicos, de 1978, inaugurou uma frente de leitura da obra machadiana por via da teoria da desconstrução, dando a ver o processo de construção da realidade, pelo narrador, no interior da linguagem.

16 A referência, aqui, é à célebre crítica de Machado de Assis a O primo Basílio, de Eça de Queiroz, em que o brasileiro acusa o português se substituir, nesse romance, o principal (o contraste de caracteres) pelo acessório (elementos circunstanciais). Helen Caldwell (1960), no capítulo 2 de seu (The Brazilian Othello of Machado de Assis), já havia notado que o narrador Dom Casmurro substitui o principal pelo acessório, quando, por exemplo, toma a suposta semelhança de Ezequiel a Escobar como prova da traição de Capitu - esse é o seu "lenço de Desdêmona". 
que a sua tragédia não é de fato essa. É antes a mais profunda tragédia implícita que o levou a constatar: "mas falto eu mesmo, e esta lacuna é tudo".

E, alternativa e consequentemente, o caso a favor da filiação da história do memorialista do Engenho Novo à do príncipe da Dinamarca foi sustentado por Marta de Senna (2009, pp. 88-89), nos anos 2000:

Importa que verifiquemos estar lidando com um narrador dissimulado, que desorienta deliberadamente o leitor, conduzindo-o por pistas falsas. E, se o verificamos, é porque há uma estratégia textual que habilmente desconstrói esse personagem-narrador, estratégia textual que é o resultado, insisto, da tensão, brilhantemente alcançada, entre o autor e o narrador. O narrador cita repetidamente Otelo; o autor nos convida a pensar em Hamlet. A desistência de envenenar um cão (capítulo 111) e, particularmente a hesitação em tomar o veneno que para si mesmo preparara, para castigar com seu suicídio o adultério que supõe em Capitu (capítulo 136), ecoam a atitude vacilante do príncipe quando não mata o tio (executando a vingança que lhe ordenara o espectro do pai), porque o encontrou a rezar, o que lhe assegurava escapar da danação. A astúcia é de tal ordem, que o narrador pensa "em Desdêmona inocente", mas sua atitude nada tem da do Mouro, para quem as falsas provas de Iago haviam bastado. Seu estado de espírito é idêntico ao de Hamlet, que, como ele, era um poço de dúvidas; que, como ele, sofre de uma espécie de paralisia da ação; que, como ele, acaba eliminando (só que literalmente) as pessoas erradas.

A crítica shakespeariana frequentemente chama a atenção para o retardamento da ação em Hamlet, que seria uma estratégia dramática para que a peça pudesse efetivamente existir, com toda a sua problemática. A crítica machadiana [...] aponta o desequilíbrio da narrativa de Dom Casmurro, que chega "ao meio do livro" com o melhor ainda por contar. ${ }^{17}$

A trama de Dom Casmurro começa a descolar-se da de Otelo a partir do momento em que se compreende que o tema principal da peça de Shakespeare (e de suas adaptações para o teatro lírico) não é o do ciúme, mas o da vulnerabilidade ao mal. David Laiches (1963, p. 275) recupera um juízo de Coleridge, segundo o qual o verdadeiro epítome do ciúme, no repertório shakespeariano, é o Leontes de Conto de inverno; em Otelo, é preciso um esforço tremendo de Iago e, até mesmo, certo lance do acaso, para que o mouro se convença da traição de sua mulher. Ao contrário

17 No ensaio de 2009, do qual o fragmento foi retirado (porque lapidar), a crítica aborda a relação de Dom Casmurro com Hamlet de passagem, a título de exemplo do caráter dissimulado do narrador-personagem. É no seu ensaio de 2008 que ela analisa detidamente os vasos comunicantes entre o romance machadiano e a peça shakesperiana, enxergando em ambos aquilo que chama de "questão da dúvida", ou, em outras palavras, "o problema da loucura, da desrazão, aliado à (ou oriundo da) incapacidade de decidir do herói” (SENNA, 2008, p. 84).

Remate de Males, Campinas-SP, v.39, n.2, pp. 741-767, jul./dez. 2019 - 756 
de Bento Santiago, Otelo não é corroído por dúvidas e inseguranças: convencido por Iago da traição de Desdêmona, resta-lhe apenas lamentar-se e executar a pena devida à mulher traidora.

Ao contrário de Hamlet, que detém o vocabulário das ideias, Otelo conhece apenas a linguagem da ação: "He did not kill her in jealous rage. He made no move himself to kill his supposed rival Cassio. He killed Desdemona for the sake of his moral universe, as the only action somehow appropriate to the situation" (LAICHES, 1963, p. 276). ${ }^{18}$ Nas palavras de Northrop Frye (1992, pp. 16-17), "Se Hamlet estivesse na situação de Otelo, não haveria tragédia, porque Hamlet teria compreendido Iago num relance; se Otelo estivesse na situação de Hamlet, não haveria tragédia, porque Otelo teria transpassado Cláudio antes que saíssemos do primeiro ato". ${ }^{19}$ Em termos de "drama de caracteres", que é o que interessa a Machado de Assis, o moto da ação, em Otelo, não é a dúvida (nem o tema, consequentemente, o do ciúme), e sim a vulnerabilidade do bem: Otelo é de tal modo íntegro, que não lhe ocorre que os outros não o sejam e, assim, sucumbe à perniciosidade de Iago, espécie de alegoria do mal absoluto, herança das chamadas "moralidades" do teatro medieval. Por outro lado, Dom Casmurro aproxima-se de Hamlet, na medida em que essa é a peça shakespeariana que tem como problemas centrais a dúvida e a hesitação diante da incerteza. No plano do enredo e da caracterização de personagens, as histórias de Bento Santiago e do jovem Hamlet possuem diversos pontos em comum, os quais vale a pena destacar.

18 "Ele não a matou em um surto de ciúmes. Ele não fez menção de matar seu suposto rival, Cássio. Ele matou Desdêmona para o equilíbrio do seu universo moral, uma vez que essa seria a única ação de algum modo apropriada à situação."

19 O contraste entre as naturezas dubitativa de Hamlet e acertiva de Otelo foi notado pelo próprio Machado, em carta aberta ao amigo Salvador de Mendonça, a respeito do ator Ernesto Rossi, publicada no jornal A Reforma, em 20 de julho de 1871. De acordo com João Roberto Faria e Adriana da Costa Teles (2012, p. 34), nessa carta aberta "Chamam a atenção as palavras dedicadas às interpretações dos papéis shakespearianos, bem como algumas revelações que faz o nosso escritor. Ficamos sabendo, por exemplo, que a peça de Shakespeare que mais admira é Hamlet. Como nunca a tinha visto no palco, confessa que teve um sonho realizado, graças a Rossi. Mais que isso: os desempenhos do ator o fizeram compreender melhor a densidade das peças encenadas. Observe-se [...] a expressão com a qual Machado caracteriza o personagem Hamlet: 'tipo eterno de irresolução e de dúvida'. A compreensão desse traço do personagem, que está presente em suas ações e no famoso monólogo 'To be or not to be', acompanhará o escritor ao longo da sua carreira, assim como a dimensão da violência do ciumento Otelo, que na interpretação de Rossi abalou os nervos da plateia”. 
Tanto Bento quanto Hamlet são órfãos de pai, e os seus dramas giram em torno de um acerto de contas com a paternidade. Ambos querem fazer justiça a uma figura paterna afrontada: Hamlet quer vingar o pai, que fora assassinado por Claudio; Bento quer vingar a si próprio, cuja paternidade fora eliminada pela suposta traição de Capitu. Claro está que a suposição dessas mortes baseia-se exclusivamente no testemunho dos fantasmas que assombram Hamlet e Bento, fora e dentro deles mesmos, e que o compromisso dos dois com a vingança dos supostos assassinatos paternos deve-se menos a laços afetivos do que à necessidade de restaurar uma ordem patriarcal rompida. Um forte componente edípico perpassa as duas personagens: Hamlet quer vingar-se de Claudio não apenas por este ter-lhe assassinado o pai, mas por ter tomado o lugar deste no leito materno, lugar que, na ausência do rei Hamlet, caberia a ele, príncipe Hamlet. Já Bento, criado à barra da saia da mãe, a "santíssima” D. Glória, quer vingar-se de Capitu, quiçá entre outros motivos, por ela sacá-lo de sua fantasia edípica. E se Hamlet esteve, durante a infância e a juventude, sob os cuidados do bobo da corte do palácio de seus pais - Yorick -, também Bentinho foi criado pelo bufão da casa senhorial em que vivia - José Dias. ${ }^{20}$

Tanto Hamlet quanto Bento, representantes dos nichos mais privilegiados das sociedades a que pertencem, parecem vislumbrar para si, constantemente, um horizonte de negociação com o divino. Em Hamlet, esse horizonte se materializa na noção de Purgatório, espaço de purificação das almas, situado a meio caminho entre o Inferno e o Paraíso, na cartografia cristã da Vida Eterna. Jacques Le Goff (1993) revela, entretanto, que o Purgatório é bastante mais recente e mais mundano do que seus territórios adjacentes: sua concepção é uma concessão da teologia católica à perspectiva mercantil, que obtinha visibilidade conforme a classe burguesa ganhava centralidade na sociedade, a partir da Baixa Idade Média. A primeira menção ao Purgatório em um documento pontifical foi feita por Inocêncio IV, em 1254, em uma carta ao cardeal Eudes de Châteauroux; vinte anos depois, no segundo Concílio de Lyon, em 1274, o termo foi chancelado pela escolástica (LE GOFF, 1993, pp. 329-330); meio século mais tarde, ele seria chancelado pela poética, com a Divina comédia de Dante Alighieri (p. 395). Stephen Greenblatt (2013, p. 17) argumenta

20 Atente-se para certa semelhança rítmica, no nome das duas personagens: y-ó-rick / jo-sé-dias. A propósito de significações onomásticas - que jamais devem ser subestimadas tanto no teatro de Shakespeare quanto na ficção de Machado de Assis -, se Ofélia é aquela que se oferece em sacrifício, Capitu é a cabeça. 
que a concepção do Purgatório não apenas tranquilizava a burguesia, que desse modo podia escapar de uma condenação post-mortem, antes sem recurso, e fortalecia o poder da Igreja, que monopolizava o comércio de indulgências, como também criava uma espécie completamente nova de relação entre os vivos e os mortos, uma vez que as almas em purgação não se encontravam em um lugar definitivo, como o Inferno e o Paraíso, e ainda possuíam alguma conexão com aquelas encarnadas - que podiam orar, interceder por elas, por exemplo.

Na Inglaterra elisabetana, protestante, a noção de Purgatório não encontrou solo propício para se enraizar, tanto que ela já não aparece em Milton. Sem embargo, Shakespeare a evoca em Hamlet - assim como evoca a de vingança pessoal, que igualmente não encontrava boa acolhida, naquele tempo e lugar (PROSSER, 1971, p. 94) -, para figurar a relação do príncipe da Dinamarca com o mundo dos mortos e seu suposto poder de intervenção sobre ele: afinal, a vingança de Hamlet-filho visa à intercessão sobre a alma de Hamlet pai, o Fantasma.

Já em Dom Casmurro, a negociação com o divino se expressa por meio daquilo que Bluma Vilar (2006, pp. 209-210) chamou de "contabilidade moral": "Há em Dom Casmurro um expressivo conjunto de metáforas econômicas aplicadas à esfera religiosa: o narrador-protagonista descreve a relação do indivíduo com Deus como relação de dívida”. A relação com Deus, para Bentinho, é uma em que Deus é sempre credor e ele, Bentinho, sempre devedor; sirva de exemplo o Capítulo XX, "Mil padres-nossos e mil ave-marias", em que o narrador conta como, quando jovem, sistematicamente renovava o seu débito de orações. A propósito, Vilar também chama atenção para o vocabulário marcadamente vinculado ao campo da economia, utilizado pelo narrador-personagem, como no capítulo LXVII, quando pensa na morte da mãe e menciona a "moeda fiduciária”, ou no capítulo LXXX, ao falar da promessa e consequente dívida da mãe em relação a ele mesmo, dizendo que "romperia o contrato".

Em Hamlet, a morte não é somente um elemento do enredo, desfecho de determinadas personagens; ela é um dos temas principais, figurado e tratado de forma material, por meio de caveiras, de alusões a vermes e a corpos em decomposição. No ato IV, cena 3, quando questionado sobre o paradeiro de Polônio, o príncipe responde que ele está numa ceia, "Not where he eats, but where he is eaten: a certain/ convocation of politic worms are e'en at him. Your/ worm is your only emperor for diet: we fat all/ creatures else to fat us, and we fat ourselves for/ maggots" 
(SHAKESPEARE, [s.d.4]). O leitor brasileiro imediatamente identifica a passagem como uma das fontes da "Dedicatória" de Brás Cubas: "Ao verme/ que/ primeiro roeu as frias carnes/ do meu cadáver/ dedico/ como saudosa lembrança/ estas/ Memórias póstumas" (ASSIS, 2009, [s.p.]). Contudo, também em Dom Casmurro os vermes banqueteiam; apenas, em vez de roerem cadáveres, roem livros:

- Meu senhor - respondeu-me um longo verme gordo -, nós não sabemos absolutamente nada dos textos que roemos, nem escolhemos o que roemos, nem amamos ou detestamos o que roemos; nós roemos./ [...] Talvez esse discreto silêncio sobre os textos roídos fosse ainda um modo de roer o roído (ASSIS, 2010, [s.p.]).

O episódio ocupa o capítulo XVII, “Os vermes", e a analogia entre os livros e o corpo humano torna-se evidente, quando se tem em mente que todo o episódio é narrado por um sujeito de papel. ${ }^{21}$

O exame exaustivo dos memento mori espalhados pela peça de Shakespeare e pelo romance de Machado de Assis tomaria muitas páginas. Fiquem anotadas, aqui, apenas a narração da morte de Ofélia e a cena do cemitério, em Hamlet; e a descrição dos padecimentos de Manduca, a praga da lepra sobre Ezequiel e o desdém final sobre Capitu e Escobar - "A terra lhes seja leve!" -, em Dom Casmurro. Por fim, observe-se que as últimas palavras do narrador-personagem de Machado de Assis ecoam cinicamente a fala derradeira da personagem de Shakespeare: o capítulo que encerra Dom Casmurro tem como título a pergunta - "E bem, e o resto?" (ASSIS, 2009, [s.p.]) - que o protagonista de Hamlet parece responder, antes de expirar: "O resto é silêncio" (SHAKESPEARE, [s.d.3], V 2). ${ }^{22}$

Se não bastassem os argumentos internos da narrativa, acima elencados, para estabelecer Hamlet como a peça shakespeariana que deixou marcas mais profundas em Dom Casmurro, dois argumentos externos poderiam ser evocados: Hamlet foi o livro que Machado de Assis escolheu para levar consigo, quando subiu a serra rumo a Nova Friburgo, para convalescer da enfermidade que o acometeu, em 1878; e o epíteto

21 Foi Eugênio Gomes (1961, p. 170) quem notou a presença dos vermes na peça de Shakespeare e nos romances de Machado de Assis, sem, entretanto, ter-se detido sobre o assunto.

22 "The rest is silence". Helen Caldwell (1960, p. 127) recorda o duplo sentido de "rest", que tanto pode significar "resto, aquilo que sobra", quanto "descanso, morte”. A crítica norte-americana pontua, ainda, que para Bento Santiago, corroído até o fim pelas suas dúvidas e amarguras, o resto não é silêncio (p. 127).

Remate de Males, Campinas-SP, v.39, n.2, pp. 741-767, jul./dez. 2019 - 760 
preferido pelo Bruxo do Cosme Velho para referir-se ao Bardo de Straftord-upon-Avon era o de "o divino autor de Hamlet". ${ }^{23}$

O diálogo com Hamlet dá nova significação ao capítulo "A ópera” de Dom Casmurro. Ao longo da peça, o jovem príncipe é sistematicamente caracterizado como um entusiasta do teatro, e uma espécie de consciência cênica perpassa todas as suas ações - vide os seus apartes, os seus solilóquios e o papel de louco que ele deliberadamente interpreta, quando no palácio. Essa consciência cênica chega a umápice no momento em que Hamlet dirige o grupo de atores que Rosencrantz e Guildenstern trazem a Elsinore, fazendo-o representar $A$ morte de Gonzaga ou $A$ ratoeira, peça que espelha os eventos relacionados ao assassinato de seu pai; então, às suas habilidades de ator, Hamlet soma as de dramaturgo e encenador. Para Harold Bloom (2004, p. 23), "Hamlet não é filósofo nem teólogo; é um entusiasta do teatro, um amador excepcionalmente bem-informado". E continua o crítico: "Shakespeare poderia ter atribuído a Hamlet os subtítulos $\mathrm{O}$ ensaio, ou Sacio com palavras meu coração, pois trata-se de uma peça sobre a atuação cênica, sobre a encenação, em lugar da vingança” (p. 23). No ato III, cena 2, quando a trupe se apresenta para o rei Cláudio e a rainha Gertrudes (observados, dos bastidores, por Hamlet), tem lugar um mise en abîme que se poderia chamar de terceiro grau: não apenas a peça Hamlet contém uma peça, como essa peça mimetiza a trama da peça Hamlet. O resultado dessa operação é a equiparação entre a realidade de dentro e de fora do palco, no interior de Hamlet, ou seja, uma demonstração do tópos do theatrum mundi - de que o monólogo de Jaques, o melancólico, em As you like it (SHAKESPEARE, [s.d.1], II 7), seria a forma mais acabada: "All the world's a stage/ And all the men and women merely players".

A metáfora "a vida é uma peça" é encenada no ato III, cena 2 de Hamlet, assim como a metáfora “a vida é uma ópera” é narrada no capítulo IX de Dom Casmurro. No entanto, a visão do mundo como representação que elas encerram não está circunscrita a essas passagens; pelo contrário, é ela que circunscreve a peça e o romance como um todo. Em primeiro lugar, por meio da consciência cênica de Hamlet e da consciência narrativa de Dom Casmurro, já examinadas. Em segundo lugar, pelo desnudamento de uma forma teatral. Hamlet traz para o plano da trama elementos da linguagem dramática, como a marcação de

23 Aspectos biográficos indicados em: Gomes (1961, p. 169). 
cena - mais de uma vez personagens dizem umas às outras onde devem postar-se -, o ensaio - personagens repetem falas, por exemplo, e observam as performances umas das outras -, a preocupação com a elocução - como quando o fantasma é instado a falar - e a presença de objetos em cena como objetos de cena - basta lembrar da caveira de Yorick.

Dom Casmurro, por sua vez, descreve o espaço das ações como cenários: o teto da sala principal da casa de Matacavalos (como o da de sua sucedânea, a do Engenho Novo), com os medalhões de César, Augusto, Nero e Massinissa, assemelha-se ao de uma sala de espetáculos; ${ }^{24}$ a casa da praia da Glória, convenientemente situada, possui portas e janelas pelas quais o leitor-espectador podeassistiràs entradas e saídas dos donos da casa e suas visitas, ao Bento que observa as estrelas, à Capitu que acompanha as marés com seu olhar, ao Escobar que se afoga; e, na cena da denúncia, no capítulo III, Bentinho assiste à conversa dos adultos, escondido atrás de uma porta, assim como um ator que observa o público, dos bastidores, por trás das cortinas. Além disso, em Dom Casmurro, a progressão do enredo se dá através de uma sucessão de cenas, de momentos do passado reencenados no discurso do narrador; poder-se-ia ler o romance, assim, como uma espécie de roteiro, em que intercalam-se cenas - os eventos do passado atualizados no presente da narrativa - e distintos tipos de rubricas: descrições de personagens, comentários metanarrativos (ou metalinguísticos), orientações (ou condicionamentos) para a recepção do texto, e monólogos reflexivos, em que o narrador faz as vezes de comentarista da cena que acabou de ser exibida (DIEGO, 2017, p. 142).

Finalmente, em terceiro lugar, a visão do mundo como representação, que atravessa de fio a pavio tanto Hamlet quanto Dom Casmurro, devido à temática da dúvida que preside à construção das duas obras. A dúvida, para o príncipe dinamarquês como para o ex-seminarista brasileiro, surge da armadilha da verossimilhança, ou seja, da impossibilidade de distinção entre o que pode ter acontecido e o que aconteceu, em função da polivalência dos signos, em um universo feito de linguagem. Por um lado, as duas personagens são cultoras das letras: Hamlet é um leitor (a rubrica, no ato II, cena 2, diz que "Hamlet entra em cena, lendo", e quando Polônio

\footnotetext{
24 Vide, por exemplo, a descrição dos medalhões que decoravam o salão do Teatro Provisório, depois Lírico Fluminense, feita por Ayres de Andrade (1967, v. 2, p. 28), a partir de um fragmento de folhetim do Jornal do Commercio: "O teto está coberto de medalhões que o enfeitam sem lhe dar realce: Auber, Bellini, Taglioni, Bibienna, Verdi, Donizetti, Schiller, Catalani, Servandoni e Meyerbeer. Fora desse círculo, isolado entre palmas e louros, aparece Rossini, como príncipe de todas essas ilustrações".
} 
pergunta ao príncipe o que ele lê, este responde: "Palavras, palavras, palavras" (SHAKESPEARE, [s.d.2], II 2) - revelando que, para ele, mais importante do que o conteúdo da leitura é a prática da leitura), e Bento é um escritor (as suas memórias podem ser lidas, inclusive, como um livro sobre a preparação para a escrita da História dos subúrbios). Por outro, são assombradas por fantasmas, por vozes do passado que atualizam pulsões atávicas e escapam aos seus processos de simbolização. Assim,

[...] a cena em que Hamlet entra lendo é um momento de transição entre duas tradições e dois modos de entender o sentido. [...] Essa tensão e essas ideias novas estão encarnadas no livro que ele lê, simplesmente um signo de um novo modo de pensar, oposto à tradição da vingança. A legendária indecisão de Hamlet poderia ser vista como um efeito de incerteza da interpretação, das múltiplas possibilidades de sentido implícitas no ato de ler. [...] Seria possível afirmar que Hamlet vacila porque se perde na vacilação dos signos. Se afasta, tenta afastar-se, de um mundo para entrar em outro. De um lado parece estar o sentido pleno, embora enigmático, da palavra que vem do Além; do outro está o livro. No meio, está o palco (PIGLIA, 2006, pp. 36-37).

A leitura em paralelo de Hamlet e Dom Casmurro, além de revelar a peça como importante fonte para a composição do romance, permite que se enxergue uma manobra efetuada pelo autor brasileiro: enquanto Shakespeare encena a metáfora "a vida é uma peça" dentro de uma peça, Machado de Assis narra a metáfora "a vida é uma ópera” dentro de um romance. Em outras palavras, o mise en abîme ocorre, em Hamlet, inteiramente no interior de uma linguagem - o teatro -, ao passo em que, em Dom Casmurro, ele atravessa duas linguagens - a ópera e o romance.

Para concluir este percurso de leituras, cumpre retornar à provocação feitaanteriormente, a partirdolivrodeHelen Caldwell:Seria Dom Casmurro, de fato, o Otelo brasileiro de Machado de Assis? A própria crítica norteamericana parece responder a essa pergunta, no capítulo "Shakespeare Under the Southern Cross", em que discute a presença de outros intertextos shakespearianos em Dom Casmurro, em especial de Hamlet e Macbeth. Sobre a primeira dessas duas peças, comenta: "As Hamlet the poet-lover, became Hamlet the murderer, so the gentle Bento became 'casmurro'. Is not this 'the rest'? By putting Iago and Othello in the same man, Machado de Assis made a Hamlet" (CALDWELL, 1960, p. 129). Acerca da segunda, revisita o tema da ambição e da pusilanimidade, que caracterizam tanto o general escocês quanto o bacharel fluminense (p. 133). É a própria autora de The Brazilian Othello of Machado de Assis, portanto, quem revela que, havendo no romance machadiano traços fortes de mais de uma peça 
shakesperiana, o privilégio dado à intertextualidade entre Dom Casmurro e Otelo é circunstancial, motivado, talvez, mais por fatores externos do que internos ao texto - do mesmo modo que a centralidade dada aos diálogos entre Dom Casmurro e Hamlet, aqui, também é circunstancial. O exame dessas circunstâncias, em um e em outro caso, seria objeto de todo outro ensaio, por isso fica aqui apenas uma sugestão: se, nos Estados Unidos de meados do século XX, em um contexto intelectual protofeminista, foi o resgate da relação de Dom Casmurro com Otelo que permitiu que se enxergasse o silenciamento da voz feminina no romance, então talvez, no Brasil de princípios do século XXI, em um ambiente político marcado por uma trágica inflexão misógina, o resgate da relação de Dom Casmurro com Hamlet permita que se enxergue o despotismo resultante de uma crise profunda do masculino.

\section{$\overline{\text { REFERÊNCIAS }}$}

ANDRADE, Ayres de. Francisco Manuel da Silva e seu tempo: 1808-1865. Rio de Janeiro: Tempo Brasileiro, 1967.

ASSIS, Machado de. Do teatro: textos críticos e escritos diversos. Organização, estabelecimento de texto, introdução e notas de João Roberto Faria. São Paulo: Perspectiva, 2008a.

ASSIS, Machado de. Ressurreição. Edição eletrônica preparada por Marta de Senna. 20o8b. Disponível em: <http://machadodeassis.net/hiperTx_romances/obras/ressurreicao. htm>. Acesso em: 20 maio 2019.

ASSIS, Machado de. Dom Casmurro. Edição eletrônica preparada por Marta de Senna. 2010. Disponível em: <http://www.machadodeassis.net/hiperTx_romances/obras/ domcasmurro.htm>. Acesso em: 20 maio 2019.

ASSIS, Machado de. Papéis avulsos. Edição eletrônica preparada por Marta de Senna. 2012. Disponível em: <http://www.machadodeassis.net/hiperTx_romances/obras/ papeisavulsos.htm>. Acesso em: 20 maio 2019.

ASSIS, Machado de. Memórias póstumas de Brás Cubas. Edição eletrônica preparada por Marta de Senna. 2009. Disponível em: <http://www.machadodeassis.net/hiperTx_ romances/obras/brascubas.htm>. Acesso em: 20 maio 2019.

AZEVEDO, Sílvia Maria. Machado de Assis e o Otelo de Shakespeare. Machado de Assis em linha 2, Rio de Janeiro, Fundação Casa de Rui Barbosa, 20o8, pp. 26-40.

BAPTISTA, Abel Barros. O legado de Caldwell, ou o paradigma do pé atrás. Santa Barbra Portuguese Studies, Santa Barbara, v. 1, 1994, pp. 145-177. 
BARTHES, Roland. Aula: aula inaugural da cadeira de Semiologia Literária do Colégio de França. 18. ed. Trad. e posf. Leyla Perrone-Mosés. São Paulo: Cultrix, 2010.

BLOOM, Harold. Shakespeare: a invenção do humano. Trad. José Roberto O’Shea, rev. Marta Miranda O’Shea. Rio de Janeiro: Objetiva, 2000.

BLOOM, Harold. Hamlet: poema ilimitado. Trad. José Roberto O’Shea. Inclui texto original de "Hamlet”, traduzido por Anna Amélia de Queiroz Carneiro de Mendonça. Rio de Janeiro: Objetiva, 2004.

CALDWELL, Helen. The Brazilian Othello of Machado de Assis: A Study of Dom Casmurro. Berkeley/Los Angeles: University of California Press, 1960.

DIÁRIO DE NOTÍCIAS do Rio de Janeiro, Rio de Janeiro. Disponível em: <http:// memoria.bn.br/DocReader/docreader.aspx?bib=369365\&pasta $=a$ no $\% 20$ 189\&pesq=Mancinelli>. Acesso em: 20 maio 2019.

DIEGO, Marcelo. Experiência e apropriação na técnica narrativa de Papéis avulsos. Machado de Assis em linha 1, Rio de Janeiro, Fundação Casa de Rui Barbosa, 2008, pp. 111-127.

DIEGO, Marcelo. "Meu amigo e comborço": dimensões homoeróticas do Dom Casmurro de Machado de Assis. Luso-Brazilian Review, Madison (University of Wisconsin Press), v. 54, n. 1, 2017, pp. 138-158.

FARIA, João Roberto; TELES, Adriana da Costa. Machado de Assis e Shakespeare: diálogos com Hamlet e Otelo. In: SENNA, Marta de; GUIMARÃES, Hélio de Seixas. Machado de Assis e o outro: diálogos possíveis. Rio de Janeiro: Móbile Editorial, 2012, pp. 28-54.

FRYE, Northrop. Sobre Shakespeare. Org. Robert Sandler, trad. e notas Simone Lopes de Mello. São Paulo: Edusp, 1992. (Coleção Criação \& Crítica, n. 9)

GAZETADE NOTÍCIAS, Riode Janeiro. 04.09.1894. Disponível em:<http://memoria.bn.br/ DocReader/docreader.aspx?bib=103730_03\&pasta=ano\%20189\&pesq=Mancinelli $>$. Acesso em: 20 maio 2019.

GOMES, Eugênio. Shakespeare no Brasil. Rio de Janeiro: MEC, 1961.

GRANJA, Lúcia. Antes do livro, o jornal: suporte, mídia e ficção. São Paulo: Editora Unesp Digital, 2018.

GREENBLATT, Stephen. Hamlet in Purgatory. Princeton, NJ: Princeton University Press, 2013.

ILUSTRAÇÃO BRASILEIRA, Rio de Janeiro. o1.10.1876. Disponível em: <http://memoria. bn.br/DocReader/DocReader.aspx?bib=758370\&pesq=Hist $\% C_{3} \%$ B3ria\%2ode $\% 20$ Quinze\%2oDias\&pasta=ano\%20187. Acesso em: 20 maio 2019. 
JOBIM, José Luís (Org.). A biblioteca de Machado de Assis. Rio de Janeiro: Academia Brasileira de Letras/Topbooks, 2001.

JORNAL DO COMMERCIO, Rio de Janeiro. 24.08.1889. Disponível em: <http:// memoria.bn.br/DocReader/docreader.aspx?bib=364568_o7\&pasta=ano\%2o 188\&pesq=Otello $>$. Acesso em: 20 maio 2019.

LAICHES, David. A Critical History of English Literature. Vol. 1. London: Secker \& Warburg, 1963.

LE GOFF, Jacques. O nascimento do Purgatório. Trad. Maria Fernanda Gonçalves de Azevedo. Lisboa: Editorial Estampa, 1993.

MACEDO, Helder. Machado de Assis: entre o lusco e o fusco. Colóquio Letras, Lisboa, Fundação Calouste Gulbenkian, v. 121/122, 1991, pp. 7-26.

MAGALDI, Cristina. Music in Imperial Rio de Janeiro: European Culture in Tropical Millieu. Lanham, MD: Scarecrow, 2004.

PIGLIA, Ricardo. O último leitor. Trad. Heloisa Jahn. São Paulo: Companhia das Letras, 2006.

PROSSER, Eleanor. Hamlet \& Revenge. Second Edition. Stanford, California: Stanford University Press, 1971.

SARAIVA, Juracy Assmann. Dom Casmurro: confissão e representação. In: O circuito das memórias em Machado de Assis. São Paulo/São Leopoldo: Edusp/Editora Unisinos, 1993, pp. 93-146.

SAYERS, Raymond S. A caminho de Bayreuth: a música na obra de Machado de Assis. Revista Hispánica Moderna, v. 34, n. 3, 1968, pp. 776-79o.

SENNA, Marta de. O olhar oblíquo do Bruxo: ensaios machadianos. 2. ed. rev. e mod. Rio de Janeiro: Língua Geral, 2008.

SENNA, Marta de. Machado de Assis: “certo instinto de nacionalidade”. Escritos 3, Rio de Janeiro, Fundação Casa de Rui Barbosa, 2009.

SENNA, Marta de. Otelo, o mouro de Veneza, de William Shakespeare. Palestra proferida no Centro Cultural Banco do Brasil do Rio e Janeiro, em 10.04.2012.

SENNA, Marta de; DIEGO, Marcelo. Retorno a Ressurreição, um fecundo romance de estreia. Machado de Assis em linha 7, Rio de Janeiro, Fundação Casa de Rui Barbosa, 2011.

SHAKESPEARE, William. As you Like it. Ed. eletrônica do Massachusetts Institute of Technology. [s.d.1]. Disponível em: <http://shakespeare.mit.edu/asyoulikeit/index. html>. Acesso em: 20 maio 2019. 
SHAKESPEARE, William. Hamlet. Ed. eletrônica do Massachusetts Institute of Technology. [s.d.2]. Disponível em: <http://shakespeare.mit.edu/hamlet/index. html>. Acesso em: 20 maio 2019.

SHAKESPEARE, William. Measure for Measure. Ed. eletrônica do Massachusetts Institute of Technology. [s.d.3]. Disponível em: <http://shakespeare.mit.edu/measure/index. html/>. Acesso em: 20 maio 2019.

SHAKESPEARE, William. Othello. [s.d.4]. Disponível em: <http://shakespeare.mit.edu/ othello/index.html>. Acesso em: 20 maio 2019.

VASCONCELOS, Erika França de Souza. Quando nasceu Ezequiel? O significado das datas no libelo acusatório em Dom Casmurro. Luso-Brazilian Review, v. 46, n. 2 , 2009, pp. 54-75.

VILAR, Bluma Waddington. Um caloteiro devoto: a contabilidade moral em Dom Casmurro. In: ROCHA, João Cezar de Castro (Org). À roda de Machado de Assis: ficção, crônica e crítica. Chapecó, SC: Argos, 2006, pp. 179-230.

WISNIK, José Miguel. Machado maxixe: o caso Pestana. Teresa, São Paulo (Universidade de São Paulo), vv. 4/5, 2003, pp. 13-79.

Recebido: 29/05/2019

Aceito: 15/08/2019

Publicado: 27/11/2019

Remate de Males, Campinas-SP, v.39, n.2, pp. 741-767, jul./dez. 2019 - 767 